\title{
ДОСУДЕБНОЕ ОБЕСПЕЧЕНИЕ ДОКАЗАТЕЛЬСТВ НОТАРИУСОМ: ПРОБЛЕМЫ ПРАВОПРИМЕНИТЕЛЬНОЙ ПРАКТИКИ
}

\author{
(C) 2020 Скачкова О.С. \\ кандидат юридических наук \\ Самарский государственный экономический университет, Россия, Самара \\ (c) 2020 Чуракова Е. Н. \\ кандидат юридических наук \\ Самарский государственный экономический университет, Россия, Самара \\ (c) 2020 Лошкарев А. B. \\ кандидат юридических наук \\ Самарский государственный экономический университет, Россия, Самара
}

В представленной статье исследуется правовое регулирование процедуры нотариального обеспечения доказательств. В частности, большое внимание уделяется исследованию особенностей осмотра нотариусом Интернет-сайтов, которое в последнее время приобретает широкое распространение, обусловленное всеобщей цифровизацией. Автором также выявляются практические проблемы, с которыми нотариусы сталкиваются при совершении данного нотариального действия. Сформулированы некоторые рекомендательные предложения по совершенствованию процедурных моментов нотариального производства по обеспечению доказательств. Анализируется судебная практика в части признания протокола осмотра сайта, составленным нотариусом, в качестве допустимого доказательства по делу.

Ключевые слова: обеспечение доказательств, нотариус, нотариальное действие, осмотр сайта, протокол осмотра, информация, Интернет, доказательство.

Нотариальное обеспечение доказательств один из эффективных инструментов системы отечественного нотариата. В настоящий момент в российском законодательстве отсутствует легальное определение данного понятия. В научной литературе под обеспечением доказательств понимают оперативное закрепление в установленном законом порядке сведений о фактах [2]. Цель обеспечения доказательств - исключение возможности их утраты, уничтожения, непредставления, без чего невозможно будет установить истину и правильно разрешить дело.

Обеспечение доказательств нотариусом можно отнести к одному из важных инструментов защиты прав и законных интересов граждан и юридических лиц, как на досудебной стадии, так и в ходе судебного разбирательства. При этом, следует обратить особое внимание на следующее. Совершение данного нотариального действия в случаях, когда уже ведется судебное разбирательство, стала возможным только после 1 января 2015 года, в связи с внесением изменений в Основы законодательства Российской Федерации о нотариате (далее - Основы о нотари- ате) [11]. Что, безусловно, способствовало росту обращений граждан и юридических лиц к нотариусу за обеспечением доказательств.

Статья 103 Основ о нотариате содержит закрытый перечень действий нотариуса при обеспечении доказательств. Так, нотариус вправе допрашивать свидетелей, производить осмотр письменных и вещественных доказательств, а также назначать экспертизу [3].

Современное общество отличается высоким уровнем развития компьютерных информационных технологий и систем телекоммуникаций. В стремительно развивающемся информационном обществе с каждым годом растет число пользователей сети Интернет, большое количество информации, в том числе юридически значимой, находится в электронном виде.

В связи с этим особую актуальность приобретает вопрос защиты прав интеллектуальной собственности, поскольку за последние голы возросло количество правонарушений в сфере нарушения авторских прав, распространения сведений, порочащих честь, достоинство и деловую репутацию. Указанные обстоятельства 
способствуют росту количества обращений к нотариусу в целях совершения осмотра и фиксации информации, размещенной в сети Интернет, для последующего предоставления данной информации в качестве доказательства по делу в суде. В последние годы распространение получило такое нотариальное действие, как осмотр Интернет-сайта.

Информацию в сети Интернет можно легко изменить или удалить, а также она может быть утрачена по иным причинам, например, в процессе обновления Интернет-сайта. Таким образом, для данного вида информации не характерно свойство постоянности, в связи с чем, гражданам или юридическим лицам необходимо предпринимать незамедлительные действия в целях фиксации достоверной информации. Одним из таких действий является обращение к нотариусу за обеспечением доказательств.

О широком использовании осмотра Интернет-сайта в рамках обеспечения доказательств нотариусом свидетельствует судебная практика, как судов общей юрисдикции, так и арбитражных судов. Так, по делу о защите исключительных авторских прав ООО «ЕвроСтрой» в качестве доказательства, подтверждающего незаконное использование ответчиком логотипа и макетов товара истца, представило протокол осмотра сайта, на котором находилась информация о контрафактном товаре и через который данный товар реализовывался. Данное доказательство было признано судом допустимым [7].

По другому делу ООО «Аналогия» обратилось в Ленинский районный суд г. Самары к гражданину К. с требованием о взыскании компенсации за нарушение исключительных прав на произведения. Истец указывал на то, что ответчик допустил 10 случаев размещения 8 фотографий, исключительные права на которые принадлежат истцу. В качестве доказательства указанного факта в материалы дела истец предоставил протокол осмотра сайта, составленный нотариусом. Суд признал протокол осмотра сайта допустимым доказательством и учел его при принятии решения [10].

По делу о взыскании компенсации за нарушение исключительного права на товарный знак истцом, в целях фиксации факта использования объектов интеллектуальной собственности, был произведет осмотр сайта. Нотариусом был засвидетельствован и отображен в протоко- ле осмотра факт использования на данном сайте товарных обозначений сходных до степени смешения с товарными знаками правообладателя. При этом ответчик принадлежность сайта не оспаривал. При указанных обстоятельствах протокол осмотра сайта был признан судом надлежащим доказательством [9].

Анализ судебной практики свидетельствует о том, что нотариально оформленный протокол осмотра Интернет-сайта становиться одним из важных доказательств при рассмотрении дел по такой категории, как защита авторских прав.

В соответствии со статьей 103 Основ о нотариате при обеспечении доказательств нотариусу необходимо известить сторон и заинтересованных лиц о времени и месте совершения нотариального действия. Следует отметить, что неявка указанных лиц не выступает в качестве препятствия для выполнения действий по обеспечению доказательств.

Между тем, нормы законодательства содержат возможность совершения действий по обеспечению доказательств без извещения одной из сторон и заинтересованных лиц. Данная возможность предусмотрена для случаев, которые не терпят отлагательств.

Федеральная нотариальная палата указывает на то, что нотариус фиксирует факт размещения информации в сети Интернет для осуществления впоследствии защиты прав, нарушенных ввиду обнародования такой информации. Поскольку информация, размещенная в сети Интернет, в любой момент может быть безвозвратно утрачена, то осмотр и фиксация такой информации являются действиями, нетерпящими отлагательств. При этом извещение нотариусом заинтересованных лиц о времени и месте проведения осмотра информационного ресурса в сети Интернет может привести к утрате доказательства, за обеспечением которого к нотариусу обратился заявитель, вследствие чего заявитель лишится возможности доказать в суде факт нарушения своего права [5].

Таким образом, осмотр Интернет-сайта в большинстве случае является ситуацией, которая требует незамедлительных действий. Данное положение также подтверждается позицией судов. Так, Арбитражный суд Амурской области в своем решении указывает на то, что осмотр и фиксация информации, размещенной в сети Интернет, должны осуществляться безотлагательно. Это необходимо в целях отражения достоверной 
информации на текущий момент времени. При извещении нотариусом заинтересованных лиц, в том числе и правонарушителя, данная цель не будет достигнута [6].

На настоящий момент процедура обеспечения доказательств, в том числе осмотр информации в сети Интернет, российским законодательством четко не определена. Общие положения содержатся в статьях 102 и 103 Основ о нотариате и Регламенте совершения нотариусами нотариальных действий, устанавливающий объем информации, необходимой нотариусу для совершения нотариальных действий, и способ ее фиксирования, утвержденный Приказом Минюста России от 30.08.2017 № 156. Нотариус при обеспечении доказательств путем осмотра сайта в сети Интернет руководствуется общими положениями, а также нотариальной практикой совершения указанного нотариального действия.

Осмотр информации в сети Интернет осуществляется по письменному заявлению лица, обратившегося к нотариусу. В ходе осмотра Интернет-сайта нотариус может установить следующую информацию:

- принадлежность того или иного доменного имени информационного ресурса, другими словами, установить владельца сайта;

- проверить соответствие символьного адреса сайта его реальному IP-адресу (это необходимо в целях удостоверения факта отображения страницы подлинного сайта браузером);

- отобразить необходимую информацию, которая содержится на конкретном сайте [12].

Объем зафиксированной нотариусом информации зависит от воли заявителя. Именно лицо, обратившееся за совершением нотариального действия, самостоятельно определяет ту информацию, которая должна быть зафиксирована.

В связи с этим считаем необходимым отметить основную функцию нотариуса при совершении данного нотариального действия. Она выражается в содействие заявителю в обеспечении тех доказательств, которые им указаны. При этом нотариус не затрагивает вопрос определения состава необходимых доказательств.

По результатам осмотра сайта нотариусом составляется протокол осмотра. Поскольку на настоящий момент отсутствует действующий нормативно-правовой акт, который устанавливал бы перечень сведений, обязательных для включения в протокол осмотра, считаем возможным обратиться к Методическим рекомен- дациям по совершению отдельных видов нотариальных действий нотариусами Российской Федерации, которые на сегодняшний день утратили силу.

Согласно Методическим рекомендациям протокол осмотра должен включать в себя следующую информацию:

- дату, время и место нотариального действия;

- сведения о нотариусе, производившем осмотр информации, а также сведения о лицах, принимавших участие при совершении нотариального действия;

- обстоятельства, обнаруженные при осмотре [4].

При этом в протоколе нотариусу необходимо детально и последовательно отобразить содержащуюся на Интернет-сайте информацию и действия, совершаемые нотариусом, в целях ее получения. В протоколе осмотра обязательно должна содержаться информация, указывающая на технические средства, с помощью которых производился осмотр. При этом нотариус должен производить осмотр информации на сертифицированном оборудовании с использованием лицензионных программ. В настоящее время в ходе осмотра информации, размещенной в сети Интернет, нотариусы используют компьютерную программу «Tracert». Данная программа позволяет отслеживать маршруты и пути, которые проходит IP-пакет для достижения цели.

Использование пиратских программ при обеспечении доказательств может быть расценено судом как получение доказательства с нарушением федерального закона. В соответствии с пунктом 4 статьи 64 Арбитражного процессуального кодекса Российской Федерации (далее АПК РФ) использование доказательств, которые получены с нарушением федерального закона, является недопустимым [1]. При указанных обстоятельствах, такое доказательство будем исключено судом из числа доказательств по делу.

K протоколу об обеспечении доказательств подшиваются распечатанные скриншоты интернет-сайта. Следует отметить, что отдельно от протокола скриншоты не имеют доказательственной силы, поскольку являются лишь приложением к протоколу, которое позволяет наглядно продемонстрировать сведения, содержащиеся в протоколе.

Между тем, ряд действий, совершаемых нотариусом, имеют технический характер. Данное 
обстоятельство на практике вызывает определенные трудности у нотариусов. Так, например, возникают трудности при формулировании произведенных нотариусом действий, так как нотариусу необходимо овладеть специальной терминологией в сфере компьютерных и информационных технологий. Также протокол осмотра может быть легко оспорен, если в нем нотариус не зафиксировал ряд технических вопросов, например, каким образом было установлено соединение с сетью Интернет.

Думается, подобные проблемы, касающиеся процедурных моментов, требуют более подробного правового регулирования на уровне федерального законодательства. Представляется целесообразным, закрепление нормы, которая предусматривала бы право нотариуса при осмотре информации в сети Интернет приглашать специалиста в IT-сфере, в целях дачи разъяснений консультативного характера по вопросам информационных технологий.

Для того чтобы информация, размещенная в сети Интернет, могла приобрести статус процессуального доказательства, она должна быть представлена в материалы дела в определенной форме.

Согласно пункту 1 статьи 75 АПК РФ письменными доказательствами являются содержащие сведения об обстоятельствах, имеющих значение для дела, договоры, акты, справки, деловая корреспонденция, иные документы, выполненные в форме цифровой, графической записи или иным способом, позволяющим установить достоверность документа.

Судебная практика свидетельствует о том, что в протокол осмотра сайта, составленный нотариусом, признается судом в качестве письменного доказательства.

В большинстве случае такое письменное доказательство, как нотариальный протокол осмотра сайта, в соответствии со статьей 68 АПК РФ признается судами доказательством, отвечающем критериям допустимости. Однако есть примеры, свидетельствующие об обратном.
Например, Арбитражным судом Самарской области протокол осмотра сайта был признан недопустимым как не отвечающим требованиям статьи 68 Арбитражного процессуального кодекса Российской Федерации. Суд указал на отсутствие в конкретной ситуации обстоятельств, не терпящих отлагательств. В связи с этим извещение сторон и заинтересованных лиц является обязательным при обеспечении доказательств. Таким образом, были нарушены нормы законодательства в части извещения лиц [8].

Обеспечение доказательств, в том числе осмотр информации в сети Интернет, в последние годы становиться одним из востребованных нотариальных действий. Наделение нотариусов полномочиями по обеспечению доказательств, способствует облегчению процедуры отстаивания прав и законных интересов граждан и юридических лиц в суде.

Современная информатизация практически всех сфер общественной жизни обуславливает развитие нотариальной деятельности, повышает значимость многих нотариальных инструментов, в числе которых нотариальное обеспечение доказательств. Но, несмотря на востребованность указанной процедуры, правоприменительная практика демонстрирует несовершенство правового регулирования самой процедуры совершения нотариального действия по обеспечению доказательств. Например, требуется детальная регламентация действий нотариуса при проведении процедуры обеспечения доказательств, размещенных в сети Интернет. В статье 103 Основ целесообразно закрепить указание на способ обеспечения доказательств, как осмотр информации в сети Интернет. А также внести изменения в Регламент совершения нотариусами нотариальных действий, устанавливающий объем информации, необходимой нотариусу для совершения нотариальных действий, и способ ее фиксирования, а именно закрепить положения, предусматривающие порядок действий нотариуса при осуществлении данного нотариального действия.

\section{Библиографический список}

1. Арбитражный процессуальный кодекс Российской Федерации от 24.07.2002 № 95-Ф3 (ред. от 02.12.2019) // Собрание законодательства РФ. 2002. № 30. Ст. 3012.

2. Двойникова Д.А. Роль нотариуса в обеспечении доказательств на примере составления протоколов осмотров Интернет-сайтов // Синергия наук. 2018. № 21. С. 835-845.

3. Основы законодательства Российской Федерации о нотариате // Российская газета. 1993. № 49. 
4. Приказ Минюста РФ от 15.03.2000 № 9 «Об утверждении Методических рекомендаций по совершению отдельных видов нотариальных действий нотариусами Российской Федерации» (утратил силу) // Бюллетень Минюста РФ. 2000. № 4.

5. Письмо Федеральной нотариальной палаты от 13.01.2012 № 12/06-12 «Об обеспечении нотариусом доказательств» // Нотариальный вестник. № 4. 2012.

6. Решение Арбитражного суда Амурской области от 23 сентября 2019 г. по делу № А04-8385/2018 [Электронный ресурс] // URL: https://sudact.ru (дата обращения: 09.03.2020).

7. Решение Арбитражного суда г. Москвы от 25 июля 2019 г. по делу № A40-142447/2018 [Электронный ресурс] // URL: https://sudact.ru (дата обращения: 07.03.2020).

8. Решение Арбитражного суда Самарской области от 1 апреля 2019 г. по делу № А55-22390/2018 [Электронный ресурс] // URL: https://sudact.ru (дата обращения: 09.03.2020).

9. Решение Арбитражного суда Красноярского края от 28 августа 2019 г. по делу № А33-16765/2019 [Электронный ресурс] // URL: https://sudact.ru (дата обращения: 15.03.2020).

10. Решение Ленинского районного суда г. Самары от 21 февраля 2019 г. по делу № 2-204/2019 [Электронный pecypc] // URL: https://sudact.ru (дата обращения: 07.03.2020).

11. Федеральный закон от 29.12.2014 № 457-ФЗ (ред. от 03.07.2016) «О внесении изменений в отдельные законодательные акты Российской Федерации» // Собрание законодательства РФ. 2015. № 1 (часть I). Ст. 10.

12. Чагаева О.В. Обеспечение электронных доказательств // Инициатива в образовании: проблема интерпретации знания в современной науке. 2019. С. 117-120. 